\title{
小児腸重積症の再発
}

\author{
武蔵野赤十字病院外科 \\ 江崎昌 俊” 久 米 進一郎2 \\ 高 橋 勝 三(部長)
}

埼玉医科大学第 2 外科

里見昭石田清(教授)

\section{RECURRENT INTUSSUSCEPTION IN INFANTS AND CHILDREN}

Masatoshi ESAKI ${ }^{1)}$, Shinichiro KUME and Katsumi TAKAHASHI

Department of Surgery, Musashino Red Cross Hospital, Tokyo

1)(Surgical Division, Institute of Clinical Medicine, University of Tsukuba, Ibaraki)

Akira SATOMI and Kiyoshi ISHIDA

Second Department of Surgery, Saitama Medical College

乳幼児腸重積症402例（特発性は395例）でそのうちの15例汇再発を認めた。性比は男12 人, 女 3 人である。最終再発時年龄は 5 力月から 3 藏 7 力月までで平均 10 力月であった。 再発までの期間は初回整復後の翌日から 2 年に及んだが，1 回めの再発が 6 力月以内に発 生したものか12例（80\%）を占めた，再発回数では1 回再発が13例で大部分を占め，2回 再発が 1 例，9回再発か门例である.9回再発例は 2 歳を過きて再発防止の手術を行なっ たにもかかわらず，術後さらに3回も再発を繰り返した後，自然に再発をきたさなくなっ たものである。

経験例上文嗝的考察から，2 歳をでは非観血的療法を重視し，2 歳を過ぎて再発をみた 場合には開腹精査の適応と考元，器質的疾患の有無を術中検查し，特発性の場合，再登防 此の手術としては本症の成立機転に腸管の異常可動性, 回盲部の固定不十分が主な条件で あることを考虑すると，回腸と上行結晹間の最低 $10 \mathrm{~cm}$ にわたる広汎な固定が必要である と思われる。

従来慣習的に行なわれてきた上行結腸と回腸間の $2 \sim 3$ 針のみの固定, ileocolic band の切離，虫垂切除なとは再発防止の普遍的手術上はなりえないことを確認した。

\section{耤 总}

乳幼児腸重積徰は小児外科の領域ではもっとも日常的 な疾患の一つであるか，その90\%以上はいまだ原因不明 であり，従ってその再発に対しては，いかに対処すべき か問題となるところである.しかし特発性腸重積の頻回 にわたる再発は比較的稀であり，その発表も少ない。

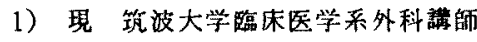

2) 現 東京医科料科大学第 2 外科
筆者らは，最近 6 回目の再発（腸重積発症 7 回）をき たした症例に対し，開腹，精查し，再発防止の手術を行 なったにもかかわらず, 術後さらに3回も再発を繰り返 し，その後，自然に発症しなくなった症例を経検した。 そこでこの経験例をもとに特発性回盲部腸重積症の原 因，再発の頻度，再発に対していかに対処すべきか，士 なわち再発防止手術の必要性の有無などについて恰討し た.

\section{1. 踭索の対象とその結果}




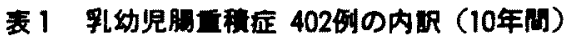

\begin{tabular}{|c|c|c|}
\hline 毛奻児渴重皘症 & 列数 & 再発例数 \\
\hline \multicolumn{3}{|l|}{ 特発性䐎重皘症 } \\
\hline （行回発症時手術施行例 & 89 & 1 \\
\hline 制回発症時ハリウム薄行例 & 306 & 14 \\
\hline \multicolumn{3}{|l|}{ 器稘的病变（手術例） } \\
\hline (Meckel氏慗室 & 3 & \\
\hline 眀黄腸管組織进残 & 2 & 0 \\
\hline 重複膈管 & 1 & \\
\hline パイエル板ポリープ状䐈大 & 1 & \\
\hline 合 & 402 & 15 \\
\hline
\end{tabular}

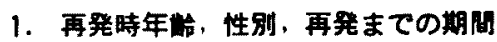

過去 10 年間仁 402 例の乳幼児晹重皘症を経験し，15例 に再発を認めた。最終再発時年龄は 5 力月から 3 歳 7 力 月まで平均 10 力であった。性比は男 12 人，女 3 人であ る. 再発までの期間は, 初回整復後の翌日から 2 年に及 んだが，1回めの 再発が半年以内に起ったものが12例 (80\%) を占めた。

\section{2. 再吐率, 再発回数}

本症402例のらち器筫的疾患を除外したいわゆる特発 性回盲部重皘症は395例であるが，そのうち15例に再発 を認めた（小児特発性腸重積症全体に扑ける再発率= $15 / 395 \times 100=3.7 \%$ ）(表 1 ).

15例 の内訳は，1 回再発（腸重積発症 2 回）かi13例 (86\%) で大部分を占め， 2 回再発が 1 例，9回再発 （発症10回でこのらちの 3 回は術後再発）が1例であ る.

重糟の型は ileo-colic type ( 3 筒性) が14例, ileoileo-colic type ( 5 筒性)が1例であった。

特発性腸重積症395例中，起回発症時ハリウム注腸に よる整復を施行したものは306例で，その5ちの14例 (1 回再発12例， 2 回再発 1 例, 9 回再発 1 例) 加再発 している（パリウム注腸後の再発率 $=14 / 306 \times 100=4.5$ $\%)$.

一方，特発性腸重棈症の初回発症時，手術を施行した ものは89例で, そのらちの1例が1回の再発をきたした (観血的整復後の再発率 $=1 / 89 \times 100=1.1 \%$ ).

なお明らかな器質的病変を有するるのはわずか 7 例で あったが，この7例においてては手術前後を通して再発を 認めていない(表 1).

1 回再発例に批いては，13例中11例に初回時上同様バ
表 2 渴工掼应再発の経過（症例）K.K. 1974年 1 月18日生

\begin{tabular}{|c|c|c|c|}
\hline 発症回数 & 発应年月 日 & 年 齿 & 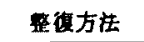 \\
\hline 第 1 回 & 1974. 8. 17 & 7 カ月 & \multirow{7}{*}{ 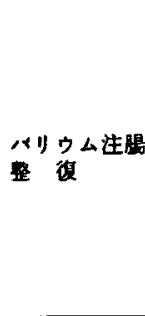 } \\
\hline 第 2 回 & 12. 2 & 11カ月 & \\
\hline 第 3 回 & 12. 3 & 11カ月 & \\
\hline 第 4 回 & 1975.7 .4 & 1 歳 5 カ月 & \\
\hline 第 5 回 & 7.5 & 1 蔵 5 力月 & \\
\hline 第 6 回 & 1976. 1.1 & 1 戴11力月 & \\
\hline 第 7 回 & 4.14 & 2 咸 3 力月 & \\
\hline 開望精查 & 5.27 & 2 歳 4 力月 & \\
\hline 第 8 回 & 9.7 & 2 或 7 力月 & ハリリカム注湟 \\
\hline 第 9 回 & 11.5 & 2 歳10力月 & \multirow{2}{*}{$\begin{array}{l}\text { 空気注入法に } \\
\text { 上る得 }\end{array}$} \\
\hline 第10回 & 1977. 8.20 & 3 葴 7 力月 & \\
\hline
\end{tabular}

以後 2 年間再発を認めす桡康である

リウム注腸による整復を行なっており，2 例は注腸整復 が不成功のため観血的整復を行なっている．2回再発 （発症 3 回）の1例は毎回注腸整復を行なって括り，そ の後の再発はない。

次に 9 回再発例について報告する.

\section{3. 应例}

思者 : K.K. 1974年 1 月18日生, 男児

主培：腹痛

既往歴：特記すべきことなし。

家族歴：兄が 1 葴の時，腸重樍症で手術をらけ，得後 死亡している。

現病歴：帝切分婏，出生児体重 $3,540 \mathrm{~g}$ 腸重積再発の 経過は表 2 に示した. 生後7カ月を最初に1日あるいは $3 \sim 9$ カ月の間隔で術前 7 回の腸重樍をおこしている. 5 回目までは他院にて注腸整復を5けており，第 3 回と 第 5 回は整復した翌日の再発であるが，いすれれる完全に 整復したにむかかからず再発したことが確かめられてい る. 当院では 6 回および 7 回目（児龄 2 嵗 4 カ月）に六 リウム注腸整復をらけた。すべて ileo-colicの3筒性と 考学られ，当院で整復した 2 回については横行結渴中央 よりやや右側にカ二爪像が得られ，バリウム整復は非常 に容易であった，過去７回も発症していること，7回目 の時は既に 2 葴を過きていること，患児の兄が腸重積症. がもとで死亡しているため家族が再発防止の手術を強く 望んでいることなどを考虑して，健康な時期を選ひ，腹 腔内精查と再発防止の目的で手術を施行した。 


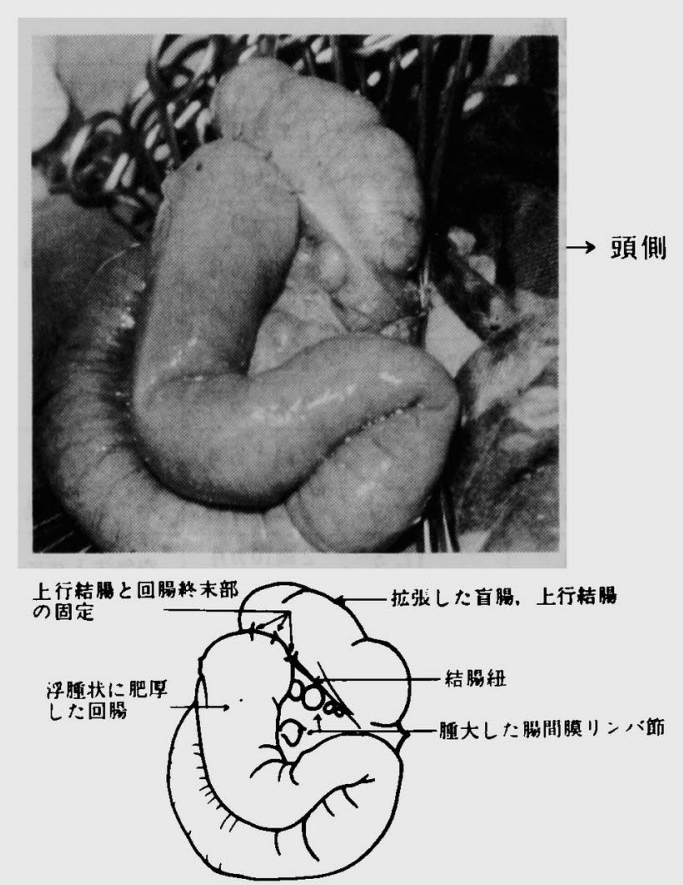

図 1 手術所見

手術所見，術式（因1）：元気で無症状な時期の手術

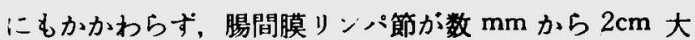
に多数腫大し，回腸終末部 $20 \mathrm{~cm}$ は浮腫状に肥厚してい た。触診上，パイエル板があずき大散在性に肥厚して いるのが認められた。盲腸〜上行結腸は径 $3.0 \mathrm{~cm}$ と払 張し、移動性に富々，腹㬵外への脱転が極めて容易であ った．虫垂は長さ $6.0 \mathrm{~cm}$ で特に変化を認めない，小腸 は回盲弁より口㑡1.5mにわたって精査したが, Meckel 顋室やポリーブなどの器質的病変は認めなかった.

ileocolic band の切離, 回腸終末部と上行結腸の固定 （回盲并の直上より $3.0 \mathrm{~cm}$ にわたり Lembert 梿合 4 針 による固定を行なったもので盲腸を腹壁に固定すること はしていない)，さらに虫垂切除術，腸間膜リンパ節生 倹を施行した。

術後経過：術後 3 力月 10 日を経て 8 回目の腸量積発症 をきたした。ささらに 9 回目，10回目と再発し，2回とも 空気注入法による非観血的整復を行なっている．10回目 の発症後現在に至る 2 年間はまったく再発を起していな い.

なお患児は腸重皘発症時以外は極めて元気であり，発 有む正常であった。

\section{II. 考}

\section{1．小児特発性回盲部重䖽症における再発の頻度}

小児腸重積症における再発の頻度は Herman ら”は12 施設の集計1,211例中 $4.1 \%$ ，松尾 (は217例中 $4.7 \%$ ，田 中"は3.9\%，本多“は $7 \%$ と報告している．棍本”は227 例中 29 例 $(12.7 \%$ ) とその頻度はもっとも高い. Soper ら゙は，再発率は初回の整復方法によってかなり異なる とし，初回整復法が観血的整復であった場合には3.17 $\%$ ，非観血的整復では $9.96 \%$ で， シリウム注腸整復法の 場台，手術的整復法に比し再発率が高いと述へている. 同様に Ein 5”も初回整復方法がパリウム注腸による場 合 $11 \%$ ，手術的整復の場合 $3 \%$ ，全体では $4.1 \%$ の再発 率であったと述べている.

一方, Benson ら゙は小巟腸重積症300例中，パリウム 注腸に扣ける再発率は $4.0 \%$ ，手術的整復例に批ける再 発率は $3.9 \%$ と報告し, 初回整復法と 1 回再発率 との間 に有意差を認めていない。

筆者らの症例群に扣いては，バリウム注腸後の再発率 は $4.5 \%$ ，観血的整復後の再発率は $1.1 \%$ ，特発性乳幼児 腸重積症全体における再発率は $3.7 \%$ (402例中15例) て あった。

\section{2. 再発までの期間と年峆}

再発は初回発症後から 6 力月以内で 2 瓷までに発生す るものが大部分である．筆者らの症例では，1回目の再 発は 6 力月以内に起ったものが80\%を占めており， 2 歳 を過ぎて発生したるのは15例中 2 例のみである。梶本 ${ }^{5}$ の報告でも大部分が 1 年以内に起っており，とくに6力 月以内のものが過半数を占めており，2 歳以内の再発は やはり $80 \%$ である. 本多ら“は注腸整復例に拊ける再発 は10力月以内 6 力月以内であったと報告している.

\section{3. 釤断}

再発の場合も初回時と同症状を呈し，間歇的腹捅発 作，呕吐，血便などが主症状となるが，経験的に初回時 より早期診断，早期治療を行ない易い傾向がある。例え ば 9 回再発例においては，腹痛の訴之万から常に患児の 両親が腸重積と確信し，救急来院する度にすぐ注腸整復 を試みていた。

初回整復後より24時間前後の再発例は整復が不完全で あったためとも考えられるので，注腸整復に際しては， 回盲弁より $70 \sim 80 \mathrm{~cm}$ は小腸を追跡する必要がある.

\section{4. 特発性回亩部渴直积症の原因}

特発性回盲部腸重積症の原因には多元的因子が関与し 
ていると考えられる。乳児ではリンパ組織増殖のため回 首并が盲腸にとび出しており，これが引き金となって先 進部が変化しなからら重積してゆく形と, 回腸末端のパイ エル板肥厚を先進部として重樍が進行する形があり，い ずれるいわゆる特発性と呼ばれている。これらリンバ組 織が強い反応を起し，腸管内人突出するには起炎莉の側 だでなく，乳児の免疫，体質の僋から検愊寸る必要が あらら。

回腸終末部のパイエル板肥厚のほか, 回盲部の異常可 動性も主たる誘因であろら．乳幼児期においては，盲 晹、上行結腸の固定が弱く移動性が大きい、さらには回 腸と結腸の管径の差が著しいここれらの条件は晹重積発

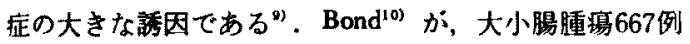
中，16例に腫㴻を原因とした腸重積を認め，対腫韵局在 頻度として小腸，横行結腸に多く，生理的に上く動く部 分に多いことを示唆しているのは興味深い。

\section{5. 再発に対する治胲}

乳幼児腸重皘症の再発に対しては，腹膜炎や腸破裂の 危㥧がある場合を除き，やはり注腸整復をまず試みる。 当院では402例中12例に 1 回再発をみているか，そのう ちの10例に注腸整復が可能であって，その後も再発を みていない，注晹整復不能の場合，すぐ手術を行ない Hutchinson 手技による整復を試みる。器質的病变や腸堙 死が諗められれば，その部を含めた腸切除を行なら．特 発性の場合，腸壊死が認められなければ整復のみにとど め，慣習的に行なわれてさた再発予防に対する処置，す なわち上行結腸上回腸 $22 \sim 3$ 㻌固定, ileocolic band の切離, 虫垂切除なとは行なら必要がないと考えてい る. その理由は、このよらな付加手術を行なわなくとも 2 回以上の再発は激減し，稀であり，また付加手術を行 なっても呈示した症例のごとく頻回に再発を繵り返す例 があるからである.上行結腸と回腸の固定は，9回再発 例の経験から2〜3針固定しても固定した全体が先進部 腫㿔となって払張した結腸に重積を起すことがあると推 測され，固定の長さに問題があると考えられる，本多” は再発防止の手術として，上行結腸に回腸末端部を $10 \mathrm{~cm}$ 程程合固定する二連銃式固定法を推摇している.

Swenson ${ }^{11)}$ は ileocolic band かi回腸終末部を脱出き せひいてて腸重磧をひき起すとしてその切嚾を勧めて いるが，むしろ極めて稀な例と考えられ，士べての症例 にこの切離を行ならことは意味のないことであり，普遍 的手術とはなりえないであろう。

虫垂切除衍に関しては，一般的には虫垂が先進部にな
らないことは多数の手術所見から明白であり，初回手術 時, 虫垂切除を行なったにいかかからず再発をきたすこ とも既でなく，無菌的操作の上から不必要な操作上考 える。

欧米では 2 回以上の再発の場合，回盲部切除を推挼す るむのが多い(1)い，その理由は，術中腸壁の浮腫のた め小さなボリープや頽室, 翼所性腺組織などがあっても 看過したり"，そのような器質的病変が存在しない場合 でも，いわゆる特発性の原因と考えられている盲腸上行 結腸の固定不十分，回盲弁腫大，ハイェル板肥厚，腸壁 に接する腸間膜リンパ節の腫大，過剩運動，ileocolic band による毫引なとそのはか手術時確認するこよが困 難と思われる未知の病態をる一括して除去するとい5目 的のためである.確かに回盲部切除は根治的であると考 えられるが，パイェル板腫大，回亩部の固定不十分など は加龄と共に（多くは2歳以上になれば）自然消失して ゆくものであるし，また経験例のごとく2回再発あるい は9回再発の場合てむ注腸整復を繰り返しているらち に，つ、自ずから再発が起らなくなる庭例が事実多 いをた発育期におけけるビタミン $\mathbf{B}_{12}$ 吸収などの発育栄 養面む考虑寸る上根治的とはいえ侵襲が大きい、捤本” は再発時年龆におい、ては $80 \%$ が 2 歳以内であり，2 歳を 過ぎると再発はにとんど起らなくなる上い5結果から， 本症の発生基瞥としての回盲部の解剖学的特殊性が失な われる年龄を 2 歳まてとし，2歳までの再発例に対して はあくまで非観血療法に終始すべきであると述べてい る.

释験した再発例と文献の検討から，筆者らも2 歳まて は非筧血療法を重視し，2歳を過ざ再発をみた場合に は開腹精查の適応と考え，術中器質的病变の有無を検査 し，特発性の場合，本庭の成立機転に腸管の異常可動 性，回盲部の固定不十分が主な条件であることを考慮す ると，再発防止の手術としては回腸之上行結腸間の最低 $10 \mathrm{~cm}$ にわたる広汎な固定が必要と思われる。

\section{桔語}

乳幼児腸重䅡疗を 10 年間に 402 例程験し、そのうち15 例に再発を確認した。再発までの期間と再発時年龄, 再 発頻度などにつ、て若干の考察を行なった．9回再発例 の经験を中心に特発性回盲部重積症の原因, 再発防止の 手術の必要性の有無，手術方法なとについてて検討を行な った.

\section{女献}

1) Herman, B.E. and Becker, J.: Recurrent 
acute intussusception. A. Survey. Surg. Clin. N. Amer., 40: 1009, 1960.

2) 松尾泰伸：小晹回盲部腸重積症217例の再検討, 小児科, $11: 1225,1970$.

3）由中克幸, 牧野惟義, 木村幸三郎他：腸重積に 扣ける再発，死亡例の検討，日小外会誌，6： $88,1970$.

4) 本多害思，中村雅英：腸重積症の治療方針，外 科診療, $11 ： 1310,1969$.

5）梶本照穂，松浦雄一郎，川口棱示他：小児腸重 積症における再発例の検討, 日小外会誌，9： 432, 1973.

6) Soper, R.T. and Brown, M.J.: Recurrent acute intussusception in children. Arch. Surg., 89 : $188,1964$.
7) Ein, S.H. and Stephens, C.A.: Intussusception: 354 cases in 10 years. J. Pediat. Surg., $6: 16,1971$.

8) Benson, C.D., Lloyd, J.R. and Ficher, H.: Intussusception in infants and children. Arch. Surg., 86: 74, 1963.

9) 高橋勝三，久米進一郎，江崎昌俊他：特発性渴 重積症の原因と治㞠について，第14回日小外会 誌総会抄録, 1977 .

10) Bond, M.R.: Intussuscption in the adult. Brit. J. Surg., 51 : 818, 1964.

11) Swenson, O.: Intussusception. In Swenson, O. (ed.): Pediatric Surgery, New York: AppleCentury-Crofts, 1969, p. 339. 